\title{
Weathering the storm or storming the norms? Moving gender equality forward in climate-resilient agriculture
}

\section{Introduction to the Special Issue on Gender Equality in Climate-Smart Agriculture: Approaches and Opportunities}

\author{
Sophia Huyer ${ }^{1,2,3} \cdot$ Samuel Partey ${ }^{1,4}$
}

Published online: 11 December 2019

(C) The Author(s) 2019

\section{Resilient or vulnerable? What do we know about women, gender equality, and agriculture under climate change?}

Much is known about the effects of climate change on women, and most research on the topic focuses on women's greater vulnerability as a result of their reliance on natural resources, lower access to resources and information, and gender and social norms which inhibit their ability to take action and participate in making household and community decisions. Less attention is given to women's active role as agents of change, their knowledge and capacity to respond to climate impacts, or tackling of the causes of vulnerability (Dankelman 2010; MacGregor 2010; Perez et al. 2015; Huyer et al. 2015). In the area of agricultural climate adaptation, Davidson (2016) noted that research on gender has primarily focused on barriers to adaptation for women to date, finding that women-headed farming households tend to be more vulnerable to the impacts of climate change, and women in all types of households are relatively more vulnerable as well. Women farmers are less likely to adopt adaptation strategies due to financial and resource limitations and less control over land (see Jost et al. 2016;

This article is part of a Special Issue on "Gender Responsive Climate Smart Agriculture: Framework, Approaches and Technologies" edited by Sophia Huyer and Samuel Tetteh Partey.

Sophia Huyer

S.Huyer@CGIAR.ORG

1 CGIAR Research Program on Climate Change, Agriculture and Food Security (CCAFS), Wageningen, The Netherlands

2 Women in Global Science and Technology (WISAT), Brighton, Canada

3 International Livestock Research Institute (ILRI), Nairobi, Kenya

4 International Crops Research Institute for the Semi-Arid Tropics (ICRISAT), Bamako, Mali 
McKinley et al. 2018; Mishra and Pede 2017), while agricultural organizations tend to exclude female farmers from many of the benefits of extension, including access to information, tools, seed, fertilizers, and improved livestock. Davidson concludes that as a result, women are often excluded from participation in adaptation decision-making, so that their unique knowledge and needs associated with their specific roles in farming tend not to be reflected in those decisions.

The articles in this issue grapple with how climate-resilient approaches including climatesmart agriculture (CSA) can more effectively promote gender equality and women's empowerment ${ }^{1}$. How can CSA be implemented in ways that improve the situation and empowerment of women as well as men. CSA has the potential to provide a range of benefits for women in adapting to climate change, if they are able to take advantage of them (Jost et al. 2016), and in fact, research presented in this issue and elsewhere indicate that CSA can be a supporting condition for empowerment (see Farnworth et al. 2017; Hariharan et al. in this issue; Mittal 2016). This issue attempts to begin to answer the questions of what are the key issues, gaps, and constraints relating to gender equality in CSA? How can women be empowered to use CSA to improve the food security and resilience of their households and communities? At the same time, it is understood that gender equality may be a process rather than an immediate result (Gutierrez et al. in this issue).

We know that constraints to women's ability to benefit from CSA are interrelated with the gender productivity gap in agriculture. Women face barriers that significantly constrain their production and entangle them in a low productivity trap (Glemarec 2017; UN Women, UNDP, UNEP, World Bank 2015). These barriers encompass societal norms, the gender division of labor (GDOL), resource constraints (access to and use of land, water, livestock, and fisheries), no or low use of inputs (e.g., drought-adapted seeds), and limited access to information and climate services, finances, and limited participation in decision-making at all levels. Because of their different roles in agriculture and the household, women and men are exposed to different climate shocks, they experience different impacts, and they have differential abilities and capacities to respond, adapt to, and recover from climate change impacts (Huyer 2016; Jost et al. 2016; Kristjanson et al. 2017). Under a changing climate, these barriers will further constrain women's ability to adapt, and the gender gap in agriculture will continue to widen, intensifying current inequalities (Djoudi and Brockhaus 2011; Nyasimi and Huyer 2017).

Climate-smart agriculture (CSA) has the potential to bridge the gender gap by providing a range of benefits for women, if implemented in such a way that they are able to take advantage of them. In order for CSA to be a positive strategy for women, however, differences in priorities and in ability to adopt new practices between women and men of different ages and social classes need to be taken into account. For example, the gender division of labor in agriculture means that men are likely to prefer crop characteristics that will increase market value such as yield, appearance, and market demand, while women may prefer varieties that are more nutritious, better tasting, and easier to cook (World Bank, FAO, IFAD 2015). Similarly, gender differences in preferences for adaptation strategies also exist. A World Bank study in Bolivia found that men focus on large-scale community interventions such as irrigation while women prefer practical improvements such as planting new crop varieties or supplementing traditional revenue with diversified production activities (World Bank, FAO,

\footnotetext{
${ }^{1}$ Climate-smart agriculture is an approach that aims to sustainably increase productivity while helping farmers adapt their farming systems to climate change and manage climate risk more effectively. It promotes three objectives: sustainably increasing productivity, building the resilience of farming systems, and reducing greenhouse gas emissions (Campbell et al. 2016).
} 
IFAD 2015). Stemming from these differences, women and men will have different needs and priorities for training, technology, and climate information needs and priorities, based in their differing access to resources, social and gender norms, and gender division of labor (World Bank, FAO, IFAD 2015; Jost et al. 2016; Tall et al. 2014). When they are able to access CSA and climate information, they are in fact just as apt to implement CSA practices as men (Gumucio and Schwager 2019; Twyman et al. 2014).

However, CSA will not necessarily be relevant to, or beneficial for women. Some argue that CSA is a compilation of market-led and productivity-oriented practices that are antithetical to feminist approaches in agriculture for development (Collins 2018). It has the potential to entrench and solidify prevailing power and gender relations within a community if questions are not asked about who is controlling the technology and who benefits from the practice (Haapala 2018). The tendency to allocate new labor-intensive activities to women can mean they will be hesitant to adopt new adaptive practices in agriculture out of concern that their workload will increase (Beuchelt and Badstue 2013). It has been argued that "gender" research in CSA is mostly concerned with a men-women dichotomy that ignores power and social and political relations, stemming from gender, race, class, ethnicity, religion, and age (Djoudi et al. 2016; Mungai et al. 2017).

Constraints from outside agriculture also influence women's ability to adopt and benefit from CSA. In some regions, barriers such as lack of access to finance, transport, or energy to support production activities need to be addressed for women before they can start to consider adopting CSA practices. Some researchers have noted a tendency for women to adopt laborintensive CSA technologies for their own work (probably due for cost reasons) which may mitigate against other equality benefits by increasing their workloads (Mutenje et al. 2019; Farnworth et al. 2017; Arora et al. 2017; Murray et al. 2016). Inadequate infrastructure for water or transportation will increase women's unpaid care work and time expended in fetching water or taking produce to market, while social norms restrict women's public interactions, participation in decision-making, and control over resources. Conversely, better access to infrastructure can reduce women's workload and increase their incomes, while also influencing changes in gender norms. In Uganda, one result of improved access to water, electricity, healthcare, and childcare was increased participation by men in domestic and unpaid care work in the household (Butt et al. 2018; Van Houweling et al. 2012).

\section{Promoting gender equality for resilience through CSA}

Climate change research in general demonstrates glaring gaps in understanding the different adaptive strategies and capacities of men and women, and the technologies, practices, and enabling environments that will empower women (CCAFS and FAO 2013; Huyer 2016). A major challenge is to identify the context-specific technologies and supporting measures that may be needed. Which trade-offs and co-benefits from different combinations of options will benefit women and promote the transformation of agriculture and rural development in ways that promote gender equality (Beuchelt and Badstue 2013; Locatelli et al. 2015; Thornton and Herrero 2015; CCAFS (CGIAR Research Program on Climate Change, Agriculture and Food Security) 2016)? As well, while approaches for integrating gender into prioritization and impact measurement of CSA technologies and climate services have been developed and tested (Duong et al. 2016; Duong et al. 2017; Nelson and Huyer 2016; Jost et al. 2014; Gumucio et al. 2018, 2019), there continues to be a gap in understanding what are the gender 
equality aspects and results of designing and implementing CSA practices, and how gender equality or empowerment results in CSA are measured ${ }^{2}$.

Articles in this issue address these questions in two ways, by (1) analyzing the status of women and gender equality in relation to climate change and agriculture and (2) presenting methods and indicators to better understand the potential of CSA for increasing gender equality in the context of climate change.

The first group of articles presents analyses of women and gender equality in relation to climate change impacts, to inform responses by policymakers and implementers. Each identifies gender differences and gaps and assesses the opportunities to promote better options for women and men. While there is a solid base of research on the effects of climate change on women farmers (e.g. Rao et al. 2017; Jost et al. 2016), there is less understanding of conditions that will affect potential gender differences in climate change impacts, and that can support the crafting of policies and actions to address these impacts. When policymakers and implementers have better disaggregated data and knowledge about the location, agricultural contributions, and climate effects of different groups in society, they can focus their actions to more effectively reach and benefit women and other sectors of society. The first two articles in the issue, "Woman in agriculture and climate risks: hotspots for development" and "Potential of climate-smart agriculture in reducing women farmers' drudgery in high climatic risk areas," add a gender dimension to an already existing methodology to identify climate "hotspots." It compares areas that are food insecure and vulnerable to the impacts of climate change (availability, access, and utilization of food) with the level of climate change exposure affecting agricultural systems (Ericksen et al. 2011). The adapted gender methodology maps three main indicators: (i) the participation of women in agriculture, (ii) degree of climate risks (drought and floods, changes in rainfall patterns, and dependency on natural resources), and (iii) poverty in two countries: India and Nepal. The resulting maps identify "hotspots" or highrisk areas where climatic risks overlap with a high proportion of women in agriculture. While this kind of macro-level approach has been criticized for failing to take into account important differences in socioeconomic level, status, etc., which affect women's situation, it does offer a large-scale overview for policymakers and support organizations to identify those areas where the greatest climate risk and vulnerability exist.

A related tool for policymakers - gender mainstreaming - is applied to climate policy in Tanzania and Uganda in "Gender in climate change, agriculture, and natural resource policies: insights from East Africa" by Ampaire and colleagues. Since the Beijing Platform for Action was agreed by governments in 1995 , gender mainstreaming in policy has been recognized as an important step towards gender equality, promoting economic and social development and improving other development outcomes such as women's access to productive resources, increased health and nutrition, and agricultural productivity gains, among other things (AfDB 2013). However, after three decades of effort to implement this approach, including global commitments such as the Convention on the Elimination of All Forms of Discrimination against Women (CEDAW) and the implementation of gender mainstreaming mandates in

\footnotetext{
${ }^{2}$ The UN Women definition of gender equality focuses on "equal rights, responsibilities, and opportunities of women and men and girls and boys" as a precondition to "improve the development process by putting social concerns at the center." Related to equality is empowerment, which involves challenging power relations as well as formal and informal rules and practices (social norms) that regulate women's lives and constrain their opportunities. Empowerment is related to increased control over assets, resources, knowledge, and ideology, focusing on the ability of women, through increased agency, to increase their bargaining power in both public and personal lives (Batliwala 1994; Kabeer 2012; Moser 2017; Sen 1997).
} 
many countries, feminists, scholars, and practitioners are questioning the value of this strategy (Moser and Moser 2005; Rao and Kelleher 2005). These debates have prompted assessments of the effectiveness of national gender policies (Krizsan and Lombardo 2013) and of gender mainstreaming in policies, programs, projects, and institutions in general (de Waal 2006; Nhamo 2014). The article in this issue continues this analysis, in particular building on work in Latin America by Gumucio and Rueda (2015) to analyze the inclusion of gender in climaterelated policies in Latin America. Results of the analysis in East Africa show that while there has been an increase in gender responsiveness in policy in both Tanzania and Uganda as part of the global push for gender mainstreaming, important shortfalls exist. In many policies, gender issues are identified as "women's issues," rather as differences between women and men with little attention to structural inequalities such as participation in decision-making, equal rights to land and inheritance, and access to financial assets. To assess the status of gender mainstreaming in these countries, the authors reviewed 155 policy documents, development plans, and annual action plans from national, district, and sub-county/ward levels for gender references and allocations, along with district and sub-county budgets, for four consecutive financial years. The authors found that governments in both Uganda and Tanzania have made positive progress in integrating gender in policies, development plans, and implementation strategies, with a general positive shift from gender-blind policy to integration of gender as a cross-cutting issue. However, there are variations in the extent to which gender is integrated. Lack of consistency in gender mainstreaming across governance levels, insufficient budgeting for gender, and identification of actions that do not address structural inequalities are the main constraints to effective gender policymaking in these countries. This aligns with research elsewhere that indicates climate policy still has some way to go to get beyond limited, or in some cases "token," references to gender, to establishing real action on the ground (see AroraJonsson 2011; Acosta et al. 2019; Gumucio and Rueda 2015; UNDP 2016). The authors note that shortcomings in substance in gender mainstreaming could hamper efforts to bridge the gender inequality gap in Africa and meet the SDG targets. They recommend steps that can be taken to build capacity of policymakers to understand the gender dimensions of climate change as well as how gender can be meaningfully mainstreamed into policy, implementation plans, and budgets.

The fourth article, "Gender and climate risk management: evidence of climate information use in Ghana," addresses the lack of sex-disaggregated data in the climate information services (CIS) literature (Gumucio and Schwager 2019). It demonstrates the value of collecting disaggregated data in the sector, as well as the insights that gender analysis can provide in understanding gender differences in access to climate information services. Earlier research has found that reaching women with CIS often requires different channels of communication as well as different contents, to take into account differing access to technologies and different roles in agriculture (Tall et al. 2014). This research expands that understanding to assess whether mobile phone-enabled services have the potential to bridge the gender climate information gap. Coming out of an initiative to support farmers with more effective and timely climate information, the analysis presents research on gender trends in use and access to climate information services delivered through mobile phone platforms and underscores the necessity to collect sex-disaggregated data on and develop gender-responsive climate risk mitigation actions in Ghana.

The article assesses gender differences in benefits of a pilot public-private partnership between Esoko (an ICT company) and the Ghana Meteorological Agency that provided CIS to farmers through information and communication technology (ICT) platforms in two districts in 
Ghana (Lawra and Jirapa). Seasonal forecast information and agro-advisories were made available to farmers through mobile phones in different formats (voice, SMS, and call center). While evidence was emerging that climate information delivered through the Esoko platform was beneficial to farmers (Etwire et al. 2017), the gender results of the initiative were not clear. The research in this issue assessed (1) whether perceptions on climate change and variability differ between men and women farmers; (2) whether gender is a determinant of climate information use; and (3) whether men and women benefit and face similar constraints to the use of climate information services. Results showed that while $85.2 \%$ (representing 767) of farmers were aware of climate change and its implications for their agriculture and other livelihood activities, and that while men and women were found to have similar perceptions about climate change, use of CIS may be influenced by gender. Men tended to use the service more than women, likely because they were more able to buy and use mobiles to access the climate and agro-information. Women generally used their husbands' phones. This echoes research and data from the GMSA that show that the digital gender divide is greater in ownership and control of mobiles than in access to them, and that the gap is not noticeably closing (GSMA Connected Women 2019). Nevertheless, despite these differences in access to CIS, both men and women found it beneficial for farm decision-making on issues such as when to begin land preparation, when to plant, and which crop to select. As well, both men and women were found to face similar constraints (such as poor network connectivity and limited of training) to accessing and using CIS through the Esoko platform, although women's constraints were slightly more likely to be based on resource limitations and illiteracy than men. Building on research elsewhere (Tall et al. 2014; Gumucio and Schwager 2019), the authors recommend the need to explore different dissemination channels for information for women and men, as well as design of CIS that meet gender-specific needs and capacities.

In this and other cases, CSA practices and technologies have been found to improve productivity and income for participating farmers while reducing risks, but contributions of the CSA approach to gender equality and empowerment within households are not well understood. In some cases, CSA may entrench gender inequalities, while in others, women's empowerment is a factor in CSA adoption (see Aggarwal et al. 2018; Haapala 2018; Mutenje et al. 2019). The second group of articles in this issue explores methodologies and approaches to address this knowledge gap. The approaches presented consist of both new and adapted methodologies to better understand the following: (i) gender equality in relation to CSA and climate-resilient agriculture approaches ("Potential of climate-smart agriculture in reducing women farmers' drudgery in high climatic risk areas" and "Contributing to the construction of a framework for improved gender integration into climate-smart agriculture projects monitoring and evaluation: MAP-Norway experience"); (ii) exploration of whether CSA practices can lead to greater empowerment for women and men ("Does climate-smart village approach influence gender equality in farming households? A case of two contrasting ecologies in India"); and (iii) development of indicators to measure gender equality results ("Does climatesmart village approach influence gender equality in farming households? A case of two contrasting ecologies in India" and "Contributing to the construction of a framework for improved gender integration into climate-smart agriculture projects monitoring and evaluation: MAP-Norway experience").

Khatri-Chhetri and colleagues in "Potential of climate-smart agriculture in reducing women farmers' drudgery in high climatic risk areas" focus on one critical gender equality aspect of agriculture in the context of climate change: women's work burden. As they note, there is significant concern that women are likely to be more negatively affected by climate impacts, especially in 
developing countries where they are highly reliant on natural resources for livelihoods and household well-being (IPCC 2014; Dankelman 2010; Cooper 2018; Beuchelt and Badstue 2013). Most analyses have been limited to their access to resources and decision-making (Kristjanson et al. 2017), but the effects on women's workload in agriculture could be very significant. In this context, women's agricultural activities in South Asia tend to be labor-intensive: sowing, weeding, and harvesting. Climate change impacts such as decreasing crop residues and biomass for energy and livestock feed, the need to re-sow or transplant crops, and decreases in crop yields are likely to increase women's workload more, given their involvement in these and related activities.

The authors propose a methodology to assess the labor-reducing potential for women of selected CSA technologies and practices: farmers' practice (FP), direct-seeded rice (both zero tillage and low tillage with machine), system of rice intensification (SRI), green manuring, and laser land leveling (LLL). In this approach, technologies that reduce women's labor contribution while improving agricultural productivity and income are considered to be womenfriendly technologies. Piloted in Rupandehi and Chitwan districts in Nepal, a framework was developed to understand changes in women's agricultural work as a result of the introduction of selected CSA technologies and practices. The first step is to assess the agricultural activities in which women are predominantly involved, followed by identification of the activities in which CSA would be most likely to benefit them. CSA technologies and practices in other regions that have been shown to reduce labor while increasing productivity were then selected and assessed in terms of five CSA indicators - efficiency, equity, gender, environment, and sustainability (Quinney et al. 2016).

The analysis in the pilot sites found that direct seeded rice, zero tillage machines, laser land leveling, and green manuring have potential to significantly reduce women's workloads, with direct seeded rice (zero tillage and low tillage using machine) and green manuring (GM) being the most likely to significantly reduce their labor hours. This finding is corroborated by analysis elsewhere in the region that found drum rice seeders can significantly reduce women's workload (Khan et al. 2016). However, the study in this issue did not assess women's actual access to the CSA technologies identified as potentially most useful, or their use or non-use by women. As the authors note, the interrelationship of labor-reducing technologies with other factors, such as access and control of resources, participation in decision-making about the adoption of CSA technologies, and linkages to new markets, needs further attention. This is a critical next step, since analysis elsewhere of women's use of LLL, for example, has found that constraints of socioeconomic norms and cost restrict their access to this technology (Aryal et al. 2015), despite their potentially labor-reducing effects. Khatri-Chhetri and colleagues identify a need for further research using holistic approaches to evaluate the implications of different CSA technologies and practices on men and women in different socioeconomic settings.

The final two articles propose indicators to measure gender equality results and the empowerment of women in the context of climate-resilient agriculture and natural resources. The first presents a proposed index that was tested in two regions in India-Bihar and Haryana. In "Does climate-smart village approach influence gender equality in farming households? A case of two contrasting ecologies in India," Hariharan and colleagues develop an approach to measure the empowerment of women and men in climate-smart villages $(\mathrm{CSVs})^{3}$. The Gender Empowerment Index for CSVs (GEI-CSV) was developed to assess

\footnotetext{
${ }^{3}$ The CSV approach was developed by the CGIAR Research Program on Climate Change, Agriculture and Food Security (CCAFS), where research for development sites test and validate different climate-smart agricultural approaches through participatory action research (see Aggarwal et al. 2018).
} 
gender trends in empowerment in CSVs. The Index draws on two global initiatives - the Global Gender Gap Index (World Economic Forum 2018) and the Women's Empowerment in Agriculture Index (WEAI) (Alkire et al. 2013) - to construct a framework that measures four domains of empowerment: political, economic, social, and agricultural. Indicators are identified to measure both increases in degree of empowerment (e.g., increased access to credit; better access to a mobile phone) as well as the achievement of empowerment in the form of the following: participation in village- or household-level decision-making, better control of money for various uses, and increased participation in agricultural decisions, among others. The added dimensions of the GEI-CSV include a focus on agricultural technologies and management practices in the context of climate change, as having the greatest influence on participation in agriculture in the climate context by households and household members and on agricultural production. As a result, the expanded set of agricultural indicators measures empowerment both in the recognized sense of increased decision-making in household agricultural decisions and increased incomes (CCAFS and FAO 2013) but also in relation to climate vulnerability and resilience of women and men, i.e., the ability to respond to and adapt to the impacts of climate change (Perez et al. 2015). Resilience indicators include ability to manage agricultural risk, use of climate insurance, crop diversification, and access to weather and agro-information. The GEI is customizable for different regional and agricultural contexts. The weight and number of indicators assigned to each domain in the pilot were determined in the context of the CSVs in Bihar and Haryana. For example, the weight assigned to political participation is lower because of equality measures already in place such as women's representation in local-level political bodies, but this can be changed to reflect differences in the political context in different regions.

The pilot in Bihar and Haryana found increased empowerment for both women and men in CSVs in both regions, compared with non-CSVs. For women, positive change was most evident in Haryana, where in CSVs, they experienced significant improvement in the different domains of the index, in comparison with women in non-CSVs. Results for women in Bihar showed lesser increases in empowerment, perhaps due to lower levels of literacy and socioeconomic status of women in that region. Nevertheless, women in CSVs still experienced some degree of improvement in relation to women in non-CSVs in the region. This study concludes that climate-smart approaches can increase empowerment of women and men in agriculture by increasing their resilience and adaptive capability while also increasing gender equality in decision-making and control of resources. The results here provide a basis for further exploration of the promotion of gender equality and empowerment through CSA approaches in different regions, both for comparison within and across regions, and for longer-term monitoring and assessment.

The final article by Isabel Gutierrez-Montes and colleagues proposes a set of indicators to measure equality and empowerment in CSA, based on a framework developed by the Mesoamerican Agroenvironmental Program of Norway (MAP-Norway). MAP-Norway was implemented in Central America in 2009 and uses a "climate-smart territory" approach to address poverty, food, and nutrition insecurity, gender inequality, degradation of ecosystem services, and vulnerability to climate change (Centro Agronomico Tropical de Investigacion y Enseñanza (CATIE) 2013). It incorporates a set of gender indicators for local and household levels; the regional level with businesses and territorial governance platforms; and the national level. As the authors note, the quantitative indicators used by MAP-Norway produce a useful overview of decision-making patterns among household members and at different levels in business and governmental organizations. They go beyond simplistic counting of numbers of 
women and men in organizational and social contexts, to include indicators that can provide useful signals about the degree and nature of gender equality — such as how many businesses have gender-sensitive statutes or recruitment processes that address gender equity issues.

However, as the authors also point out, quantitative data is insufficient to measure changes in gender roles and status in different contexts, and may be misleading. Gender respondent biasbias in opinions about the role and work of household members - is a known risk for household surveys. This is supported by recent research in Uganda which found that women reported joint household decision-making more often than men, who presented themselves more often as the sole decision-makers; and in Western Kenya where women and men gave different responses relating to control and decision-making around the sale of milk (Tavenner et al. 2018; Acosta et al. 2019). Based on work with focus groups, the authors propose a set of qualitative indicators to assess decision-making for agricultural productivity and food security. They include, for example, questions on both women and men's perceptions of women's roles and workload in household, community, and business organizations. They also propose quantitative indicators to get at gender results in agricultural productivity in assessing the use by female-headed households of farm equipment, fertilizers, and pesticide, as well as distribution of assets within a household. This set of indicators can be a model for the development of gender indicators for adaptation and mitigation in CSA, for example, to monitor issues such as access to water for irrigation and household use. The authors recommend that mixed methods of qualitative and quantitative approaches be applied to deepen and enrich analysis of gender equality in CSA, for project planning and implementation at all levels in both the public and private sectors.

\section{Conclusion}

Climate change is expected to exacerbate poverty and increase vulnerability in most developing countries, and create new poverty areas in countries with increasing inequality. The IPCC predicts that climate change will also exacerbate existing gender inequalities, adding to the vulnerabilities already experienced by rural women in the developing world. Without recognition of the role women play in adapting to climate change, global gender inequalities will increase - including the gender gap in agriculture. The articles in this issue present new opportunities and approaches that need to be tested, replicated, and scaled up. CSA and agriculture for development will need to grapple with the challenge of gender equality if the threats posed by climate change are to be tackled and the world is to reach the $2^{\circ}$ target.

Acknowledgments This work was implemented as part of the CGIAR Research Program on Climate Change, Agriculture and Food Security (CCAFS), a strategic partnership of CGIAR and Future Earth, led by the International Center for Tropical Agriculture (CIAT). We acknowledge the CGIAR Fund Council, Australia (ACIAR), European Union, International Fund for Agricultural Development (IFAD), Ireland, New Zealand, Netherlands, Switzerland, USAID, UK, and Thailand for funding the CCAFS.

Open Access This article is licensed under a Creative Commons Attribution 4.0 International License, which permits use, sharing, adaptation, distribution and reproduction in any medium or format, as long as you give appropriate credit to the original author(s) and the source, provide a link to the Creative Commons licence, and indicate if changes were made. The images or other third party material in this article are included in the article's Creative Commons licence, unless indicated otherwise in a credit line to the material. If material is not included in the article's Creative Commons licence and your intended use is not permitted by statutory regulation or exceeds the permitted use, you will need to obtain permission directly from the copyright holder. To view a copy of this licence, visit http://creativecommons.org/licenses/by/4.0/. 


\section{References}

Acosta M, van Wessel M, van Bommel S, Ampaire EL, Twyman J, Jassogne L, Feindt PH (2019) What does it mean to make a 'joint' decision? Unpacking intra-household decision making in agriculture: implications for policy and practice. J Dev Stud 0(0):1-20. https://doi.org/10.1080/00220388.2019.1650169

AfDB (2013) Investing in gender equality for Africa's transformation. https://www.afdb. org/fileadmin/uploads/afdb/Documents/Policy-Documents/2014-2018___Bank_Group_Gender_Strategy.pdf. Accessed: 6 June 2017

Aggarwal PK, Jarvis A, Campbell BM, Zougmoré RB, Khatri-chhetri A, Vermeulen SJ, Huyer S et al (2018) The climate-smart village approach: framework of an integrative strategy. Ecol Soc 23(1):14

Alkire S, Meinzen-Dick R, Peterman A, Quisumbing A, Seymour G, Vaz A (2013) The Women's Empowerment in Agriculture Index. World Dev 52. https://doi.org/10.1016/j.worlddev.2013.06.007

Arora-Jonsson S (2011) Virtue and vulnerability: discourses on women gender and climate change. Global Environ Chang 21(2):744-751. https://doi.org/10.1016/j.gloenvcha.2011.01.005

Arora D, Arango J, Burkart S, Chirinda N, Twyman J (2017) Gender [im] balance in productive and reproductive labor among livestock producers in Colombia: Implications for climate change responses. CCAFS Info Note. Copenhagen, Denmark: CGIAR Research Program on Climate Change, Agriculture and Food Security (CCAFS)

Aryal JP, Mehrotra MB, Jat ML (2015) Impacts of laser land leveling in rice - wheat systems of the north western indo-gangetic plains of India. Food Secur 7:725-738. https://doi.org/10.1007/s12571-015-0460-y

Batliwala S (1994) The meaning of women's empowerment: new concepts from action. In: Sen G, Germain A, Chen L (eds) Population policies reconsidered: health, empowerment, and rights. Harvard Center for Population and Development Studies, Boston

Beuchelt TD, Badstue L (2013) Gender, nutrition- and climate-smart food production: opportunities and tradeoffs. Food Secur 5(5):709-721. https://doi.org/10.1007/s12571-013-0290-8

Butt A P, Remme J, Rost L, Koissy-kpein S A (2018) Exploring the need for gender-equitable fiscal policies for a human economy: evidence from Uganda and Zimbabwe. Oxford: Oxfam. https://doi.org/10.21201/2017.1725

Campbell BM, Vermeulen SJ, Aggarwal PK, Corner-Dolloff C, Girvetz E, Loboguerrero AM, Ramirez-Villegas J, Rosenstock T, Sebastian L, Thornton P (2016) Reducing risks to food security from climate change. Global Food Secur 11:34-43. https://doi.org/10.1016/j.gfs.2016.06.002

CCAFS (CGIAR Research Program on Climate Change, Agriculture and Food Security) (2016) Full Proposal 20172022. CGIAR Research Program on Climate Change. Agriculture and Food Security (CCAFS), Copenhagen

CCAFS and FAO (2013) Gender and climate change research in agriculture and food security for rural development. FAO, Rome

Centro Agronomico Tropical de Investigacion y Enseñanza (CATIE) (2013) Desarrollo rural sostenible en dos territorios climáticamente inteligentes de Centroamérica (Proyecto MAP-Noruega). Available: http://infoagro.net/archivos Infoagro/Ambiente/proyectos/Doc_CompletoMAP-N.pdf. Accessed 5 Dec 2019

Collins A (2018) Saying all the right things? Gendered discourse in climate-smart agriculture. J Peasant Stud 45(1):175-191. https://doi.org/10.1080/03066150.2017.1377187

Cooper M (2018) Using natural areas and empowering women to buffer food security and nutrition from climate shocks: evidence from Ghana, Zambia, and Bangladesh. IFPRI - Discussion Papers (1717) vi-pp. Retrieved from http://ebrary.ifpri.org/utils/getfile/collection/p15738coll2/id/132366/filename/132577.pdf. Accessed 5 Sept 2019

Dankelman I (2010) Introduction: exploring gender, environment, and climate change. In: Dankelman D (ed) Gender and climate change: an introduction. Routledge, London

Davidson D (2016) Gaps in agricultural climate adaptation research. Nat Clim Chang 6:433. Retrieved from. https://doi.org/10.1038/nclimate3007

de Waal M (2006) Evaluating gender mainstreaming in development projects. Dev Pract 16:209-214

Djoudi H, Brockhaus M (2011) Is adaptation to climate change gender neutral? Lessons from communities dependent on livestock and forests in northern Mali. Int For Rev 13(2):123-135. https://doi.org/10.1505 $/ 146554811797406606$

Djoudi H, Locatelli B, Vaast C, Asher K, Brockhaus M, Basnett Sijapati B (2016) Beyond dichotomies: gender and intersecting inequalities in climate change studies. Ambio 45. https://doi.org/10.1007/s13280-016-0825-2

Duong MT, Simelton E, Le VH (2016) Participatory identification of climate-smart agriculture priorities. CGIAR Climate Change, Agriculture and Food Security Program, Copenhagen

Duong TM, Smith A, Le TT, Simelton E, Coulier M (2017) Gender-differences in agro-climate information services. CGIAR Research Program on Climate Change. Agriculture and Food Security (CCAFS), Copenhagen

Ericksen P, Thornton P, Notenbaert A, Cramer L, Jones P, Herrero M (2011) Mapping hotspots of climate change and food insecurity in the global tropics (CCAFS Repo). CGIAR Research Program on Climate Change. Agriculture and Food Security (CCAFS), Copenhagen 
Etwire PM, Buah S, Ouédraogo M, Zougmoré R, Partey ST, Martey E, Dayamba SD, Bayala J (2017) An assessment of mobile phone-based dissemination of weather and market information in the upper west region of Ghana. Agric Food Secur 6(1):1-9. https://doi.org/10.1186/s40066-016-0088-y

Farnworth CR, Stirling C, Sapkota BT, Jat ML, Misiko M, Attwood S (2017) Gender and inorganic nitrogen: what are the implications of moving towards a more balanced use of nitrogen fertilizer in the tropics? Int J Agric Sustain 15(2):136-152. https://doi.org/10.1080/14735903.2017.1295343

Glemarec Y (2017) Addressing the gender differentiated investment risks to climate-smart agriculture. AIMS Agric Food 2(1):56-74. https://doi.org/10.3934/agrfood.2017.1.56

GSMA Connected Women (2019) The mobile gender gap report 2019. GSMA, London Retrieved from https://www. gsmaintelligence.com/research/?file=17ebe22503e597f6e4687365106d6ad6\&download. Accessed 21 May 2019

Gumucio T, Rueda MT (2015) Influencing gender-inclusive climate change policies in Latin America. J Gend Agric Food Secur 1(2):42-61

Gumucio T, Schwager S (2019) Checklist: gender considerations for climate services and safety nets. CGIAR Research Program on Climate Change. Agriculture and Food Security (CCAFS), Wageningen

Gumucio T, Huyer S, Hansen J, Simelton E, Partey S, Schwager S (2018) Inclusion of gender equality in monitoring and evaluation of climate services. CCAFS Working Paper no. 249. CGIAR Research Program on Climate Change, Agriculture and Food Security (CCAFS), Wageningen, Netherlands.

Gumucio T, Hansen J, Huyer S, van Huysen T (2019) Gender-responsive rural climate services: a review of the literature. Clim Dev 0(0):1-14. https://doi.org/10.1080/17565529.2019.1613216

Haapala A (2018) A feminist analysis of oppressive and emancipatory potentialities within technology-prioritized climate change adaptation intervention: a case study from Phailom community in Laos. In: Paris T, RolaRubzen M (eds) Gender dimension of climate change research in agriculture (case studies in Southeast Asia). CGIAR Research Program on Climate Change. Agriculture and Food Security (CCAFS), Wageningen

Hariharan VK, Mittal S, Rai M, Agarwal T, Kalvaniya KC, Stirling CM, Jat ML (in this issue) Does climatesmart village approach influence gender equality in farming households? A case of two contrasting ecologies in India. Clim Chang. https://doi.org/10.1007/s10584-018-2321-0

Huyer S (2016) Closing the gender gap in agriculture. Gend Technol Dev 20(2). https://doi.org/10.1177 $/ 0971852416643872$

Huyer S, Twyman J, Koningstein M, Ashby J, Vermeulen SJ (2015) Supporting women farmers in a changing climate: Five policy lessons. Copenhagen, Denmark. https://cgspace.cgiar.org/rest/bitstreams/60479/retrieve

IPCC (2014) Human Security. In: Field LLW, Barros VR, Dokken DJ, Mach KJ, Mastrandrea MD et al (eds) Climate change 2014: impacts, adaptation, and vulnerability, Part A: Global and sectoral aspects, Contribution of Working Group II to the Fifth Assessment Report of the Intergovernmental Panel on Climate Change. Cambridge University Press, New York

Jost C, Ferdous N, Spicer TD (2014) Gender and inclusion toolbox: participatory research in climate change and agriculture. CGIAR Research Program on Climate Change. Agriculture and Food Security, Copenhagen

Jost C, Kyazze F, Naab J, Neelormi S, Kinyangi J, Zougmore R et al (2016) Understanding gender dimensions of agriculture and climate change in smallholder farming communities. Clim Dev 8(2):1-12. https://oi. org/10.1080/17565529.2015.1050978

Kabeer N (2012) Women's economic empowerment and inclusive growth: labour markets and enterprise development. Department for International Development (DFID) and the International Development Research Centre (IDRC), London.

Khan T, Kishore A, Joshi P K (2016) Gender dimensions on farmers' preferences for direct-seeded rice with drum seeder in India. International Food Policy Research Institute. Washington DC: IFPRI. Retrieved from https:/cgspace.cgiar.org/rest/bitstreams/84185/retrieve. Accessed 5 Dec 2019

Kristjanson P, Bryan E, Bernier Q, Twyman J, Meinzen-Dick R, Kieran C et al (2017) Addressing gender in agricultural research for development in the face of a changing climate: where are we and where should we be going? Int J Agric Sustain 15(5):482-500. https://doi.org/10.1080/14735903.2017.1336411

Krizsan A, Lombardo E (2013) The quality of gender equality policies: a discursive approach. Eur J Womens Stud 20:77-92. https://doi.org/10.1177/1350506812456462

Locatelli B, Pavageau C, Pramova E, Di Gregorio M (2015) Integrating climate change mitigation and adaptation in agriculture and forestry: opportunities and trade-offs. Wiley Interdiscip Rev Clim Chang 6(6):585-598. https://doi.org/10.1002/wcc.357

Macgregor, S (2010) "Gender and Climate Change': From Impacts to Discourses.” Journal of the Indian Ocean Region 6(2):223-38

McKinley J, Adaro C, Rutsaert P, Pede VO, Sander BO (2018) Gender differences in climate change perception and adaptation strategies: the case of three provinces in Vietnam's Mekong River Delta. In Gender dimension of climate change research in agriculture: case studies in Southeast Asia. Wageningen, the Netherlands: CGIAR Research Program on Climate Change, Agriculture and Food Security (CCAFS): Wageningen, CGIAR Research Program on Climate Change, Agriculture and Food Security (CCAFS). 
Mishra AK, Pede VO (2017) Perception of climate change and adaptation strategies in Vietnam: are there intrahousehold gender differences? Int J Clim Chang Strateg Manag 9(4):501-516. https://doi.org/10.1108 /IJCCSM-01-2017-0014

Mittal S (2016) Role of mobile phone-enabled climate information services in gender-inclusive agriculture. Gend Technol Dev 20(2):200-217

Moser CON (2017) Gender transformation in a new global urban agenda: challenges for Habitat III and beyond. Environ Urban 29(1):221-236. https://doi.org/10.1177/0956247816662573

Moser C, Moser A (2005) Gender mainstreaming since Beijing: a review of success and limitations in international institutions. Gend Dev 13:11-22. https://doi.org/10.1080/13552070512331332283

Mungai C, Opondo M, Outa G, Nelson V, Nyasimi M, Kimeli P (2017) Uptake of climate-smart agriculture through a gendered intersectionality lens: experiences from Western Kenya. In: Filho WL (ed) Climate Change Adaptation in Africa pp. 587-601. Springer

Murray U, Gebremedhin Z, Brychkova G, Spillane C (2016) Smallholder farmers and climate smart agriculture: technology and labor-productivity constraints amongst women smallholders in Malawi. Gend Technol Dev 20(2):117-148. https://doi.org/10.1177/0971852416640639

Mutenje MJ, Farnworth CR, Stirling C, Thierfelder C, Mupangwa W, Nyagumbo I (2019) A cost-benefit analysis of climate-smart agriculture options in Southern Africa: balancing gender and technology. Ecol Econ 163(May):126-137. https://doi.org/10.1016/j.ecolecon.2019.05.013

Nelson S, Huyer S (2016) A gender-responsive approach to climate-smart agriculture: evidence and guidance for practitioners. FAO, Rome

Nhamo G (2014) Addressing women in climate change policies: a focus on selected east and southern African countries. Agenda 28:156-167

Nyasimi M, Huyer S (2017) Closing the gender gap in agriculture under climate change. Agric Dev 30:37-40

Perez C, Jones EM, Kristjanson P, Cramer L, Thornton PK, Fuerch W, Barahona C (2015) How resilient are farming households and communities to a changing climate in Africa? A gender-based perspective. Glob Environ Chang 34:95-107. https://doi.org/10.1016/j.gloenvcha.2015.06.003

Quinney M, Bonilla-Findji O, Jarvis A (2016) CSA indicators database summary and key findings. Copenhagen, Denmark: CGIAR Research Program on Climate Change, Agriculture and Food Security (CCAFS).

Rao A, Kelleher D (2005) Is there life after gender mainstreaming? Gend Dev 13(2):57-69. https://doi. org/10.1080/13552070512331332287

Rao N, Lawson ET, Raditloaneng WN, Solomon D, Angula M (2017) Gendered vulnerabilities to climate change: insights from the semi-arid regions of Africa and Asia. Clim Dev 0(0):1-13. https://doi.org/10.1080 $/ 17565529.2017 .1372266$

Sen AK (1997) From income inequality to economic inequality. South Econ J 64(2):384-401

Tall A, Kristjanson P, Chaudhury M, Mckune S (2014) Who gets the information? Gender, power and equity considerations in the design of climate services for farmers. CGIAR Climate Change, Agriculture and Food Security Programme, Copenhagen

Tavenner K, Fraval S, Omondi I, Crane TA (2018) Gendered reporting of household dynamics in the Kenyan dairy sector: trends and implications for low emissions dairy development. Gend Technol Dev 22:1-19

Thornton PK, Herrero M (2015) Adapting to climate change in the mixed crop and livestock farming systems in sub-Saharan Africa. Nat Clim Chang 5:830-836

Twyman J, Green M, Bernier Q, Kristjanson P, Russo S, Tall A et al (2014) Adaptation actions in Africa: evidence that gender matters. CGIAR Climate Change, Agriculture and Food Security Programme, Copenhagen Retrieved from https://cgspace.cgiar.org/bitstream/handle/10568/51391/WP83.pdf

UN Women, UNDP, UNEP, World Bank (2015) The cost of the gender gap in agricultural productivity. UN Women, World Bank, UNDP and UNEP, New York Retrieved from http://documents.worldbank. org/curated/en/847131467987832287/pdf/100234-WP-PUBLIC-Box393225B-The-Cost-of-the-GenderGap-in-Agricultural-Productivity-in-Malawi-Tanzania-and-Uganda.pdf

UNDP (2016) Gender equality in national climate action: planning for gender-responsive national determined contributions (NDCs). UNDP, New York Retrieved from http://www.undp.org/content/undp/en/home/librarypage/womensempowerment/gender-equality-in-national-climate-action\%2D\%2Dplanning-for-gender-html

Van Houweling E, Hall RP, Diop AS, Davis J, Seiss M (2012) The role of productive water use in women's livelihoods: evidence from rural Senegal. Water Altern 5(3):658-677

World Bank, FAO, IFAD (2015) Gender in climate-smart agriculture. World Bank, FAO, IFAD, Washington DC Retrieved from http://documents.worldbank.org/curated/en/654451468190785156/pdf/99505-REVISEDBox393228B-PUBLIC-Gender-and-Climate-Smart-AG-WEB-3.pdf

World Economic Forum (2018) Global gender gap report 2018. World Economic Forum, Geneva

Publisher's note Springer Nature remains neutral with regard to jurisdictional claims in published maps and institutional affiliations. 